Pobrane z czasopisma Annales H - Oeconomia http://oeconomia.annales.umcs.pl Data: 26/04/2023 14:56:51

DOI:10.17951/h.2017.51.2.203

\begin{tabular}{lcl}
\hline \multicolumn{1}{c}{ A N N A L E S } \\
UNIVERSITATIS MARIAE CURIE-SKŁODOWSKA \\
LUBLIN - POLONIA \\
VOL. LI, 2 \\
\hline
\end{tabular}

Maria Curie-Skłodowska University in Lublin, Faculty of Economics, Chair of Marketing

\author{
MONIKA RATAJCZYK \\ m.ratajczyk@umcs.pl
}

\title{
Changes in the Young Consumer's Purchasing Process
}

Zmiany w procesie zakupowym młodego konsumenta

Key words: Generation Y; purchasing process; hybrid consumer

Słowa kluczowe: generacja Y; proces zakupowy; konsument hybrydowy

JEL codes: M31; D12; D83

\section{Introduction}

In order marketing could evolve and be able to meet consumer's needs, marketers constantly need to deepen their knowledge about still changing consumers' behaviour. The globalisation of business activities and competetition in many markets additionally escalates these needs, because the basis of both segmentation and effective promotion is to understand the consumer's desires, motivations and aspirations. Without this, marketing would be simple selling but not a form of communication. However, nowadays companies need not only to talk but also to listen to consumers, because only sensitive, authentic and focused on building relationship brands can generate customers' interest. On the one hand, consumers are becoming more and more educated and aware, but on the other hand, they are also tired of a large amount of information. They do not buy the products themselves, but the desire to fulfil a particular lifestyle, which they would like to lead. Moreover, the younger the consumer, the harder it is to construct effective advertising messages for him. This article aims at exploring the changes that have taken place in the course of purchasing process among young consumers. 


\section{Young consumers}

There is no consistent typology, which would allow extracting a group of "young consumers". In the literature, it is possible to find examples where this group was described as teenage consumers, students, graduates [Kicińska 2009; Grzybowska-Brzezińska 2010]. This lack of a consistent approach means that marketing often operates in terms of "generations", which allows one to divide consumers not only because of age but also behaviourally. According to such division, there could be distinguished the following generations: the generation of Baby Boomers, Generations X, Y (Millennials) and Z. Each generation has grown up in a different socio-economic situation, struggled with other problems, which has resulted in different market behaviour.

Generation Y (consumers who are currently 20 and 30 years old) grew up in an era of prosperity, with access to the Internet and new technologies. They grew up in much smaller families, hence, they experienced more attention and care of parents, so that they could possess a "little emperor syndrome" [van den Bergh and Behrer 2011, p. 27]. They live longer at family home (in many countries this time is extended up to the age of 30), they later start their own families and they are dependent longer (at least partially) on their parents. As consumers they are much more incredulous and much more demanding [Gołąb-Andrzejak 2016]. The available research focuses mainly on ways of communicating with Generation Y and the specific behaviour of this group towards the behaviour of other generations. Naturally, depending on the country, the results vary a little (different levels of income, different intensity of social media use, different consumer awareness, etc.). There is a lack of research that analyzes the entire buying process of this group. This requires in-depth qualitative research.

\section{Methodology}

The article is based on the results of the author's qualitative research conducted in the years 2013-2016 with young consumers (18-34 years old) from Poland (mainly from Lublin). Research was carried out in three stages (the first two involved purchasing food, the last one - shopping in general). The first 7 FGIs were completed with consumers representing different attitudes towards shopping, and various shopping habits, diverse financial status and a different phase of the family development. Then, the collected information was verified and deepened during the 25 ethnography purchasing processes, which were completed with individual interviews (either in pairs, if shopping were carried out by anyone in relationships). Participants selected for the study additionally differed in housing situation (living with roommates, living at the family home, independent apartments) and in preferences for purchase places (local shops, discount store, supermarket). To fulfil collected information, virtual 
ethnographies were made, which allowed looking more broadly at the verified issue. The behaviour of young consumers in social media environment (Instagram, Pinterest, YouTube, Facebook - both at brand profiles, as well as, in consumers groups, on blogs related to the subject important for young people, i.e. motherhood, career development, broad-based lifestyle), their reactions and involvement in shared content, frequency of generating the content and talking points were analyzed.

\section{The purchasing process of a consumer from Generation $Y$}

\subsection{Awareness of the need}

The classic consumer purchasing process extracts five phases [Kieżel 1999, p. 62; Garbarski 2001, pp. 61-63]: awareness of the need, the search for information, evaluation of alternatives, purchase and after-purchase behaviour. In the context of online shopping researchers add the step of selecting an online vendor [Mącik 2013, p. 173].

Consumer from Generation Y spends a lot of time on the Internet. He spends his time in social media, mainly on portals such as Facebook, Instagram, Snapchat, Pinterest and YouTube. These portals, among others, allow one to meet needs of communication with friends, stay up to date with important information for the consumer (which takes a very individual character), so that each of the consumer creates his microcosm and his micro world and be surrounded himself with it. Millennials follow social media activities of celebrities, bloggers, and profiles of different companies and organizations constantly being under their influence. However, an impact of social media is constantly increasing and nowadays, it is not only a blog or a fanpage, but also increasingly widespread livestreaming or continued formation of groups focused around a particular topic. The result of this process impacts young consumers, who regularly observe the lifestyle of other people who - for some reason - are important to them, for example, personal trainers, freelancers, young mothers, etc. Since authenticity in marketing has become extremely important, the influencers share the moments of their life (now more and more willingly). They show their houses, food, clothes, etc. anything that could be called "lifestyle". Skilfully fuelled curiosity (e.g. diversification of the content to different channels of communication and their limited availability) engages even more young consumers who are willing to learn about other ways of life than those taught in their family homes, as well as the environment in which they were brought up. This may evoke a desire to aspire to such a life and make purchases that will enable fulfillment of this life vision, as those known from virtual environment.

It is not possible to omit the phenomenon of the emergence of more and more specialized groups on Facebook. People with similar interests and needs network in order to be able to exchange information, share experiences and support each other. Hence, not only groups about e.g. selling in general appear, but also groups that are focused on very specific products and localization (e.g. sale or exchange of 
toys for girls in Lublin). The situation seems to be similar as far as other interests are concerned. More and more standard becomes the formation of groups focused around some particular topics - starting own business, motherhood, DIY, physical exercise, etc. Members of these groups are very active, and they are more and more willing to share not only experiences with the product or service but also to boast about particular shopping (by inserting images and videos showing the process of opening packages of new products). An activity of group members is greater if the purchase was less standard, e.g. when someone found an interesting shop or a company from foreign countries with less typical (than on the local market) patterns or products solving some problems in the simplest manner. In this case, members are actively involved, willing to comment on such purchases and ask about the purchase details and then boast about their purchases later.

Interestingly, the mechanism of promotion has its important role here as well. Among young people, reselling things they no longer need gains its popularity (a visible trend among minimalist life, slow life, slow fashion). In each of such a group, they sell out items they will no longer use, e.g. clothes, books that were read, unused household appliances, etc. Lower than a regular price becomes a strong incentive to buy. Analysis of comments under posts shows that young people are able to buy the $36^{\text {th }}$ book, which is offered at a $50-70 \%$ discount off the regular price, knowing and admitting that 35 books are waiting in the queue to be read.

Nevertheless, an observation of the behaviour of young people in these groups showed their strong commitment to life of a virtual community and interaction between each other, as a result of which, many unplanned, impulsive purchases can be made. Particularly susceptible to such purchases are young women.

\subsection{Searching for information}

Studies show [Mącik 2013, pp. 189-191] that for the Generation X members, independently seeking information among family, friends (perceived as experts in their fields) or even sellers, is crucial, whereas Generation Y prefers to use the online information sources.

They seek information on forums, watch product reviews on YouTube, seek on blogs reviews made by their favourite bloggers, ask for advice on Facebook and in the groups to which they belong. They are also much more active since they not only watch or search for posts and discussions but also initiate them by themselves e.g. they are increasingly willing to insert pictures asking for advice (for instance, when they want to decorate or renovate an apartment they add a photo of the selected space and ask for advice on the arrangement). Interestingly, more and more young consumers are willing to ask also about health tips. They write about symptoms of illnesses, often inserting pictures and asking how they can be cured (e.g. skin lesions, alopecia). It could be noted here that they put considerable trust in the advice of strangers and their experiences and conclusions. It seems that the concerns of the authenticity of these tips 
are mitigated by the basic personal data, which can be found on the website (name, image) and a discussion on the advice (the more details will give a person describing the case, or be more active in later discussion, the more reliable the tip).

It is noticeable that young people intensively look for information to help them to solve their problem. They ask groups how can they fix the equipment, clean it or get rid of a problem (e.g. dampness at home). They are also open to suggestions which they receive. Also purchasing a product from a website of a foreign country is becoming less and less problematic (the popularity of AliExpress.com website is noticeable). Young consumers frequently visit foreign shops, blogs and become acquainted with the materials created in a different language (e.g. videos).

\subsection{Evaluation of alternatives}

The intensive use of social media, whether via a computer or dedicated applications, and living in virtual communities, also makes young consumers eager to make use of advice of Internet users for products they are considering to buy. Intense activity can be seen in groups clustered around the topics of ecology, diet, exercise, time management or even business running. From the perspective of life stage Millennials currently occupy this seems to be natural. What is more, it is associated with establishing a family, as well as a career path developing.

A strong awareness of the members of the group is a distinctive feature. Tips from people who are not close friends allow one to obtain information about products, which normally would be harder to get to know of. The same situation seems to be with knowledge in general. In a traditional way of asking relatives and passing down tips and advice from generation to generation it would be hard to learn about other solutions. As a result of increasing awareness of young consumers they choose to buy products from local producers, from small, less known companies (and even from people who do not have companies) or produce products by themselves.

Advice from bloggers, virtual communities, as well as ordinary, unknown persons on the network has a strong influence on purchasing decisions. Millennials are willing to use it with applications to facilitate their choice. Applications for evaluating product ingredients (food, cosmetics) and their origin gain popularity among this group. Products with the composition which seems to be "uncertain" are sent, for example, to bloggers asking for an assessment of the composition. Thanks to such requests, on blogs there are made comparisons relating to the harmfulness of the products from different categories.

\subsection{Purchase}

Changes at the stage of purchase are also visible. Young consumers prefer to use fast electronic payments or make purchases internationally. Some people appreciate the niche-oriented products, little-known brands, handmade products, while the others 
praise cheap shopping. Millennials not only buy brand new products but they also much more willingly search for second-hand things.

However, under the influence of virtual communities and information gathered on previous stages, not everyone will after all decide on purchase but rather a product they can make by themselves. The range of goods, which applies to this situation is varied: cosmetics, household chemicals, clothing, decoration and interior design. Young women sew for themselves and their families ecological sanitary napkins, reusable, cloth diapers for their children or even prepare medicinal products. They also together make purchases by sharing shipping costs. So, in effect, it is possible that the original purchasing process may not be completed or there can be launched a new one (purchase of semi-finished products needed for the independent workmanship).

\subsection{After-purchase behaviour}

Life in online communities also makes young people be much more willing to share their impressions after the purchase. The studies show [Dimensional Research 2013, pp. 1-11; Salesforce Research 2016, pp. 1-15] that consumers strongly prefer to share their negative after-purchase experiences than positive ones, but in virtual communities, people more willingly, than in the physical world, are boasting about their shopping. Perhaps this is connected with a sense though partial anonymity, the need for expression or even a lack of concern regarding the potential appraisal (boasting) what could be perceived as inappropriate behaviour in the face to face situation.

Young consumers are eager to show the photos illustrating their lifestyle (Facebook, Instagram), for example, visiting restaurants, amusement park, etc. In online groups they are more likely to show their purchases (in the form of photographs or videos) and share the emotions associated with it. Interestingly, they show almost all the stages related to the purchase, for example, showing an unopened package, recording the feeling of excitement when opening it, demonstrating how to use the product, and finally, reviewing the product and assessing the results after some time of using it. The in-depth discussion under the post allows consumers to explore the more accurate use of the product, e.g. to see the situations in which the product works and the ones in which it does not. On brand profiles, young consumers demonstrate how the product works in use (e.g. a dress worn by an ordinary person vs. the same item worn by a professional model).

It is interesting that the functioning of virtual communities limits the throwing away products, which seems to be inappropriate but allows the resale or exchange, to which young consumers are encouraged. A consumer can exchange products in the specially created groups where the exchange mechanism usually looks the same (e.g. I will give layette for a newborn in exchange for diapers in size 2).

Similar behaviour can also be observed in other cultures, for example, in South Korea, where thousands of people from Generation Y, mainly singles, every day, at a particular time, watch some food blogger (called mukbang) who just eats in front 
of a webcam (online streaming). It is also common to "live online" which means that young people live with a camera in hand non-stop recording and sharing on the web what they are currently doing (almost all day long).

\section{Implications for marketing}

Strong immersion of young consumers in the virtual world means that the authority of the brand can be easily brought into question. Brands and their products are subject to continual review and evaluation, which does not disappear but now is stored "forever" and is almost universally available. Young consumers are not so trustful as their parents and they look for further information about the brand not only on public forums, where it is more likely to meet with the reviews written on brand demand, but also in more closed communities to which joining is needed, or where discussions are deeper, and where authors creating content called a spam are quickly blocked. These customers are also more demanding, possibly due to the fact of having access and exploring many brands, not only Polish ones, hence, their expectations are rising. As a result, they are less loyal and the decision about changing the brand is easier for them, when other brand will meet their expectations.

Consumers are also becoming more educated. On the one hand, it is easier for them to make informed decisions, because they have more knowledge about the market and market practices, although - as shown in the article - it may be harder not to succumb to the temptation to "live as others" and succumb to the vision of the ideal life of others (as consumers usually only they see a nice apartment, ideal figure, etc.).

The result is that a young consumer becomes a difficult client whose expectations are harder to meet and whose loyalty is harder to obtain. Both brands and sellers are no longer authorities in giving advice. Such a role is starting to be carried out by ordinary people. Moreover, it seems that the constant participation in social media can strongly influence the popularisation of hybrid consumer attitudes, who in some categories will select the branded product and in the others - cheap. This is another challenge for marketing and the need for even greater personalization of the offer for the client.

\section{Bibliography}

Dimensional Research, Customer Service and Business Results: A Survey of Customer Service From Mid-Size Companies, 2013, pp. 1-11, https://d16cvnquvjw7pr.cloudfront.net/resources/whitepapers/ Zendesk_WP_Customer_Service_and_Business_Results.pdf (access: 21.02.2017).

Garbarski, L., Zachowania nabywców, PWĒ, Warszawa 2001, pp. 61-63.

Gołąb-Andrzejak, E., Konsumenci pokolenia Y-nowe wyzwanie dla komunikacji marketingowej, "Handel Wewnętrzny", vol. 2, no. 361, 2016, pp. 140-151. 
Grzybowska-Brzezińska, M., Młodzi konsumenci wobec społecznych instrumentów promocji wykorzystywanych na rynku żywności, "Zeszyty Naukowe Uniwersytetu Szczecińskiego. Ekonomiczne Problemy Usług”, no. 54, 2010, pp. 195-204.

Kicińska, J., Psychologiczno-społeczne determinanty zachowań młodych nabywców na rynku dóbr konsumpcyjnych, "Journal of Agribusiness and Rural Development", vol. 4, no. 14, 2009, pp. 85-94.

Kieżel, E., Rynkowe zachowania konsumentów, Wydawnictwo Uczelniane Akademii Ekonomicznej im. KarolaAdamieckiego, Katowice 1999, p. 62.

Mącik, R., Technologie informacyjne i komunikacyjne jako moderator procesów podejmowania decyzji zakupowych przez konsumentów, Wydawnictwo UMCS, Lublin 2013, p. 173.

Salesforce Research, 2016 Connected Consumer Goods Report, 2016, pp. 1-15, https://www.salesforce.com/assets/pdf/industries/connected-consumer-goods.pdf (access:12.02.2017).

van den Bergh, J., Behrer, M., Jak kreować marki, które pokocha pokolenie Y, Samo Sedno 2011, p. 27.

\section{Changes in the Young Consumer's Purchasing Process}

The consumer purchasing process is still affected by new factors. A young consumer (Generation $\mathrm{Y}$ ) remains under constant influence of social media, which includes increasing power of online consumer groups, through which they acquire new knowledge about the market, marketing practices (not always honest), the process of preparing new products (not always in ethical way). It is worth noting that a few years ago this information was considerably more difficult to access. This knowledge, as well as the increasing exhibition of individual consumption, shared in social media, affect the purchasing behaviour of young people. The article presents changes in the purchasing process of the youngest consumers adult generation, today's 20- and 30-year-olds. The article is based on the results of qualitative research (the focused group interviews, ethnography of purchasing processes and virtual ethnography) conducted in 2013-2016.

\section{Zmiany w procesie zakupowym młodego konsumenta}

Na proces zakupowy konsumenta wciąż oddziałują nowe czynniki. Młody konsument (generacja Y) nieustannie pozostaje pod wpływem działania mediów społecznościowych, w tym coraz silniej for i grup konsumenckich, dzięki którym pozyskuje nową wiedzę na temat: rynku, praktyk marketingowych (nie zawsze uczciwych), procesu przygotowywania nowych produktów (nie zawsze w sposób etyczny) - jeszcze kilka lat temu zdecydowanie trudniej dostępnej. Wiedza ta i coraz powszechniejsze eksponowanie swojej konsumpcji, którą konsument dzieli się w mediach społecznościowych, bardzo wpływają na zachowania zakupowe młodych osób. W artykule zaprezentowane zostały zmiany w procesie zakupowym najmłodszego, dorosłego pokolenia konsumentów, dzisiejszych dwudziesto- i trzydziestolatków. Artykuł opiera się na wynikach badań jakościowych (zogniskowanych wywiadach grupowych, etnografii procesów zakupowych oraz wirtualnej etnografii) prowadzonych w latach 2013-2016. 